Two other morphological features of enteropneusts further suggest that the dorsal surfaces of enteropneusts and chordates are homologous. First, enteropneusts have a putative homologue of the chordate notochord on the dorsal side of the animal, the stomochord ${ }^{10}$. Second, enteropneusts have U-shaped branchial skeletons of identical design and orientation with chordates ${ }^{6-8}$.

Before one can conclude that an inversion of the dorsoventral axis occurred at the time of origin of the chordates, minimally it must be shown that: (1) $B M P-2$ is expressed ventrally in vertebrates, and member(s) of the $d p p$ subfamily ${ }^{2}$ are expressed ventrally in 'protochordates'; (2) the dorsal nerve cord of enteropneusts and chordates are not homologues; (3) the stomochord is not the homologuc of the notochord; and (4) the pharyngeal skeletons in enteropneusts and chordates arose independently. Until then, Geoffroy's original hypothesis remains simply a matter of historical significance.

\section{K. J. Peterson}

Department of Earth and Space Sciences and IGPP

Center for the Study of Evolution and the Origin of Life,

University of California, Los Angeles,

California 90024-1567, USA

1. Arendt, D. \& Nübler Jung, K. Nature 371, 26 (1994). Kingsley. D. M. Genes Dev. 8, 133-146 (1994).

3. Patterson, C. in Problems of Phylogenetic Reconstruction (eds Joysey, K. A. \& Friday, A. E.) 21-74 (Academic, London, 1982)

4. Peterson, K. J. in Major Features of Vertebrate Evolution (eds Prothero, D. R. \& Schoch, R.M.) 14-37 (Paleont. Soc. Univ. Tennessee, Knoxville, 1994)

5. Schram, F. R. in The Early Evolution of Metazoa and the Significance of Problematic Taxa (eds Simonetta, A. M. \& Conway Morris, S.) 35-46 (Cambridge Univ. Press, 1991).

6. Brusca, R. C. \& Brusca, G. J. Invertebrates (Sinauer, Sunderland, Massachusetts, 1990).

7. Hyman, L. H. The invertebrates Vol. 5 (McGraw-Hill, New York, 1959).

8. Nielsen, C. Biol. J. Linn. Soc. 25, 243-299 (1985)

9. Sarnat. H. B. \& Netsky. M. G. Evolution of the Nervous System, 2nd edn (Oxford Univ. Press, 1981).

10. Balser, E. J. \& Ruppert, E. E. Acta zool., Stockh. 71. 235-249 (1990).

\title{
Cation selectivity in ion channels
}

SIR - Valera et $a l^{1}$. and Brake et $a l .{ }^{2}$ have reported the amino-acid sequences of members of a novel class of ligand-gated ion channel, namely the ATP-gated channel or $\mathrm{P}_{2 \mathrm{x}}$ receptor. The channel dis-

in alignment of the highly conserved TXTTXGXG motif in the $\mathrm{H} 5$ region of potassium channels ${ }^{5}$. Of particular interest is the GXG motif within the H5 region. In inwardly-rectifying and

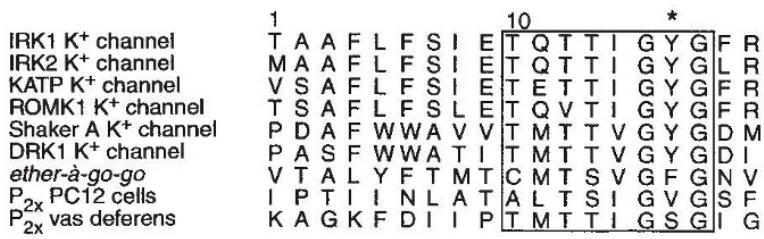

Alignment of the $\mathrm{H} 5$ region of inwardly-rectifying potassium channels (IRK1, IRK2, KATP and ROMK1), voltage-gated potassium channels (DRK1, Shaker A and ether-à-go-go) and ATP-gated channels $\left(P_{2 x}\right.$ receptors). Boxed region, highly conserved eight-residue potassium-channel signature sequence ${ }^{5}$. Asterisk, denotes the central position of the GXG motif.

plays cation selectivity when expressed in Xenopus oocytes, and both groups of authors propose a transmembrane topology similar to that of a recently cloned family of inwardly-rectifying potassium channels ${ }^{3}$, with two potential membrane-spanning helices (M1 and M2) and an intervening region, $\mathrm{H} 5$. The sequence alignment proposed by Valera $e t$ $a l .{ }^{1}$ for $\mathrm{P}_{2 \mathrm{x}}$ cloned from rat vas deferens is very similar to inward-rectifiers and voltage-gated potassium channels within its H5 region.

We would like to propose an alternative assignment for the $\mathrm{H} 5$ region of $\mathrm{P}_{2 \mathrm{x}}$ cloned from rat PC12 cells to that offered by Brake et $a l^{2}$. Our assignment was obtained by alignment of the proposed transmembrane regions of voltage-gated and inwardly-rectifying potassium channels with the $P_{2 x}$ sequences ${ }^{1,2}$, using the multiple sequence alignment package, AMPS $^{4}$. Our analysis (see figure) results 'cation- $\pi$ ' interactions in in. Thus, highly potassium-selective inward-rectifiers and voltage-gated channels exhibit a conserved tyrosine in GXG (or phenylalanine in ether-à-go-go), whereas in the nonspecific cation channels encoded by $\mathrm{P}_{2 \mathrm{x}}$ tyrosine is replaced by a smaller, nonaromatic residue ${ }^{1,2}$.

\section{I.D. Kerr}

\section{M.S.P. Sansom}

Laboratory of Molecular Biophysics,

Rex Richards Building,

University of Oxford,

South Parks Road,

Oxford OX1 3QU, UK

1. Valera S. et al. Nature 371, 516-519 (1994).

2. Brake, A.J. et al. Nature 371, 519-524 (1994).

3. Kubo, Y. et al. Nature 362, 127-133 (1993).

4. Barton, G.J. \& Sternberg, M.J.E. J. molec. Biol. 198. 327-337 (1987).

5. Heginbotham, L. et al. Biophys. J. 66, 1061-1067 (1994)

6. Brfiggemann, A. et al. Nature 365, 445-448 (1993).

7. Kumpf, R.A., \& Dougherty, D.A. Science 261. 1708-1710 (1993)
Bet on positional information

SIR - One idea of how patterns of cellular differentiation are specified during development is that first, positional information is set up in a population of cells, and second, that each cell interprets this information according to its genetic constitution and developmental history ${ }^{1}$. Recent studies have suggested that a related set of homeotic genes encode positional identity along the body axis of many animals, and it has even been suggested that this defines a zootype that all animals share ${ }^{2}$. In insects, for example, one can think of the homcotic genes as acting together to give genetic addresses, which establish segment identity ${ }^{3,4}$. Martinez Arias ${ }^{5}$ has challenged these ideas on the basis of the work of Warren et al., who have studied the expression of the homeotic gene Ultrabithorax $(U b x)$ in butterflies ${ }^{6}$.

In Drosophila, $U b x$ is expressed in the third thoracic segment which forms a haltere. In butterflies the third thoracic segment carries a wing. According to Martinez Arias, "most punters would have put their money on the absence of expression" of $U b x$ in the third thoracic segment of butterflies because he thinks the homeotic genes are associated with specific structures. But I, and other colleagues I have asked, would not have put down even a penny in support of such an idea, for the identity of a segment as specified by homeotic genes says nothing about what structures it will develop. That is the central idea of positional information. Indeed Warren et al.'s finding that in butterflies the third thoracic segment expresses $U b x$ strongly supports the idea of positional identity being specified by the homeotic genes. What has changed in evolution of the basic pattern of butterflies and flies is not the positional identity of the thoracic segments nor the deployment of homeotic genes, but their downstream targets.

\section{Lewis Wolpert}

Department of Anatomy \&

Developmental Biology,

University College London Medical School, Cleveland Street, London W1P 6DB, UK

\footnotetext{
1. Wolpert, L. Development (Suppl.) 3-12 (1989).

2. Slack, J. M. W. et al. Nature 361, 490-492 (1993)

3. Lawrence, P. A. The Making of a Fly (Blackwell Scientific, Oxford, 1992).

4. Lawrence, P. A. \& Morata, G. Cell 35, 595-601 (1983)

5. Martinez Arias, A. Nature 372, 408-409 (1994).

5. Martinez Arias, A. Nature 372, 408-409 (1994).
6. Warren, R. W. et al. Nature 372, 458-461 (1994)
}

\section{Scientific Correspondence}

Scientific Correspondence is intended to pro vide a forum in which readers may raise points of a scientific character. They need not arise out of anything published in Nature. In any case, priority will be given to letters of fewer than 500 words and five references. 